\title{
地震時に地下構造物の側壁に生じる せん断破壊を考慮した設計手法の一考察
}

\author{
金子 雅廣 1 勅使川原 敦 2 堤 純生 3 \\ 1正会員 成田国際空港株式会社＼cjkstart経営計画部（テ282-8601 千葉県成田市成田空港内NAAビル） \\ E-mail: m-kaneko@naa.jp \\ 2正会員 (株)復建エンジニヤリング 第一鉄道・地下グループ \\ （テ103-0012 東京都中央区日本橋堀留町1-11-12） \\ E-mail: teshigawara@fke.co.jp \\ 3正会員 （株)復建エンジニヤリング＼cjkstart第二鉄道・地下グループ（同上） \\ E-mail: tsutsumi@fke.co.jp
}

\begin{abstract}
数十年前に設計・施工された既設構造物と一体として新設される構造物に対し，現行の設計基準を用い て耐震設計を行うことは可能であるが，一体構造物が有すべき具体的な性能及び評価手法に対する統一さ れた合理的な考え方は未整理である.

筆者らは既往の実験成果，文献等を検討し，既設構造物側壁および下床版にせん断破壊が生じる場合に あっても，一定の条件下においてこれを考慮し，耐震性能を確認することができる耐震設計手法について 検討し，実務に有用な知見を整理した。

本論文では，設計手法検討に当たっての既往成果の工学的解釈，設計手法の特徵について述べる.
\end{abstract}

Key Words : seismic design, underground structures with existing parts and newly constructed part, shear failure, organization for promotion of civil engineering technology, JSCE

\section{1. はじめに}

「鉄道構造物等設計標準・同解説 而震設計 平成11 年10月」 ${ }^{1)}$ (以下，「而震標準」という）が制定される 以前に設計された既設の開削トンネルと新設の開削トン ネルが一体化した構造物（以下，「新旧一体地下構造 物」という）を設計する場合，新旧一体地下構造物の耐 震性能は，新設構造物と同等な要求性能を設定すること が最良であるが，既設構造物の保有性能が十分でない場 合には，経済性を考慮しつつ安全性を確保寸るための技 術的判断が要求される. 成田空港と都心との鉄道アクセ スを改善したスカイアクセス線整備においては，空港内 にある既存2駅舎に図-1に示すような増改築を施す必要 があった．新旧一体地下構造物として耐震性能を照査し た結果，既設構造物の側壁および下床版にせん断破壊が 生じることが判明した．これら駅舎は，空港への鉄道ア クセス手段として重要な施設であり，側壁および下床版 に大規模なせん断補強を行うことは運用上，投資額の面 から実質不可能な状況にあった。このため筆者らは，側 壁のせん断破壊を一定の条件下で許容しつつも，一定の
而震性能を工学的に説明できる設計手法の提案を目的と した検討を実施した。

\section{2. 既往の研究成果を基にした側壁せん断破壊後 の部材性能の把握}

せん断破壊については，既往の実規模大供試体（RC ボックスカルバート）による類似構造実験 2)33)方存在し ている．実験では中柱を含めて側壁がせん断破壊したも のの，層間変形角 : 24/1000 まで軸力保持能力を維持し

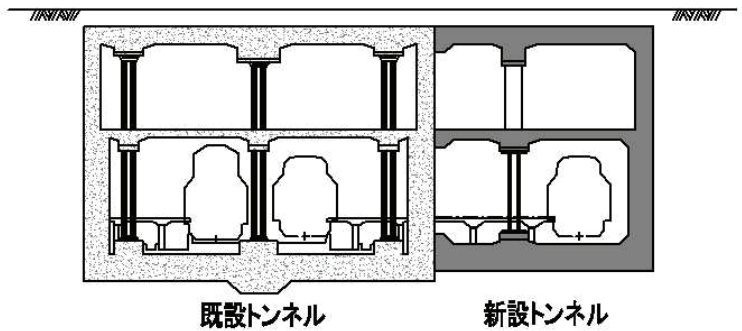

図-1 増築のイメージ 
たことが報告されている．また，奥行き方向が短い 2 次 元的な供試体に対し，実構造物は奥行き方向に長い延長 を有しており，さらに地盤の不均一性等もふまえると， ボックスカルバート延長方向の同位置に連続してせん断 破壊が発生する可能性は低いと考えられる.

以上より，実験体と類似した条件下においては，構造 物側壁のせん断破壊を許容できる可能性があると判断し， 実規模大で製作したせん断破壊先行型RCボックスカル バートを用い，水平載荷試験により水平耐力及び変形能 力を把握した曽良岡ら ${ }^{4}$ の研究成果を対象とし, せん断 破壊後の部材性能を把握することとした.

\section{(1) 既往の研究成果における実験概要}

実験に用いた供試体及び載荷状況を図-2 に示す．周 辺地盤からの土圧を模擬するために複数のジャッキを用 い，供試体の底版は PC 鋼棒を用いて試験床に固定して いる. また，試験体の形状寸法と配筋は図-3 のとおり， 幅 $9.55 \mathrm{~m}$ ，高さ $3.75 \mathrm{~m}$ ，奥行き $1.2 \mathrm{~m}$ で，部材厚さは隔壁 40cm，側壁および頂版は $75 \mathrm{~cm}$ である。 なお，せん断補 強鉄筋は側壁下端のみ折り曲げ鉄筋が配置されている.

\section{（2）実験から得られた知見等}

報告された実験結果の概要は以下のとおりである.

1) 層間変形角 7/1000 (24mm) の左一右載荷で左側壁が せん断破壊して水平荷重が約 40\%低下.

2) 層間変形角 $8 / 1000$ の右 $\rightarrow$ 左載荷で右側壁がせん断破

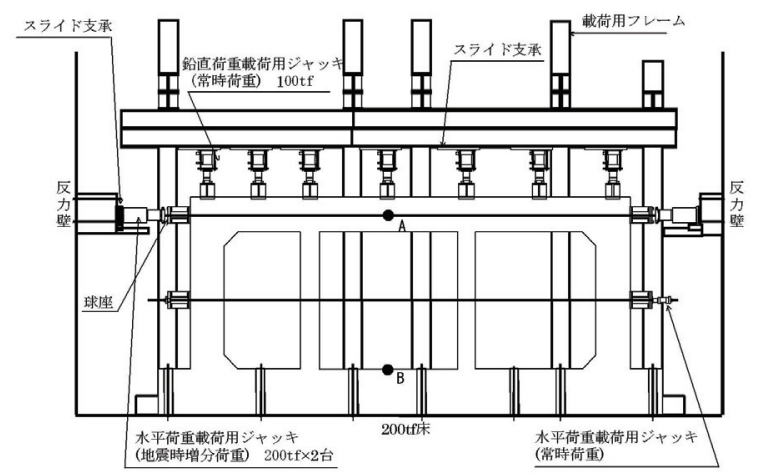

図-2 実験に用いた供試体及び載荷状況 ${ }^{4)}$

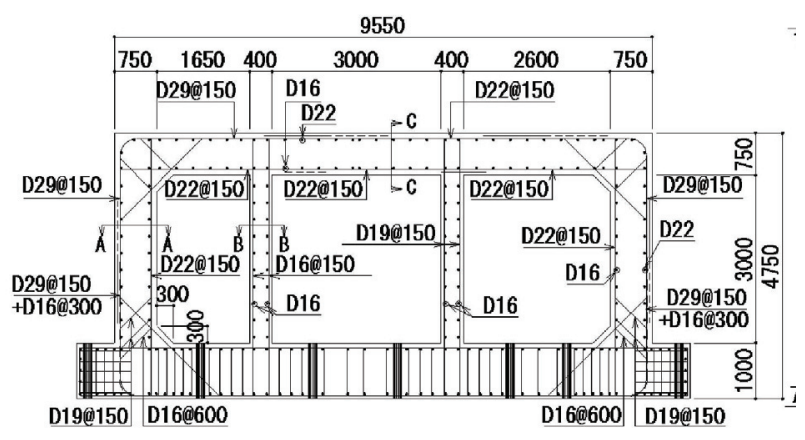

図-3 試験体の形状寸法と配筋 ${ }^{4}$
壊.

3) 交番載荷は 14/1000 まで行い，その後は一方向（右 左）に切り替えた.

4) 層間変形角 24/1000（81mm）に達寸ると右側壁の損傷 が著しくなり，常時荷重を保持できなくなる.

5) 隔壁は実験終了時までせん断破壊しなかった.

\section{3. 設計に用いるせん断破壊後の部材モデル}

\section{(1) 部材のモデル化の考え方}

「而震標準」では，一般的な地下構造物の断面方向の 耐震設計は応答变位法を用いることとしており，図-4に 示すように, 構造物は1要素長を部材厚相当と寸る線材 としてモデル化し，その非線形性（M- $\varphi$ 関係等）を考慮 している. また，構造物周囲の地盤は，構造物を支持す る地盤ばねとしてモデル化し，その非線形性は，地震時 の地盤のひずみレベルに応じた剛性低下より考慮してい る.

ここで，せん断破壊後の部材は $M-\varphi$ 関係が成立せず, 軸力伝達機能，曲げモーメント伝達機能が大きく低下寸 ることとなる。このことから，せん断破壊部位の部材モ デルには非線形性を考慮せず，軸力伝達機能の低下を断 面積の低減にて，曲げモーメント伝達機能の低下を断面 二次モーメントの低減にて表現することとした.

\section{（2）地震時における構造物の変形に係る制限値の設定}

実験におけるせん断破壊後の挙動では，層間変形角が 24/1000に至るまで軸力保持機能を有していた.

しかし，既往の実験と今回対象としている構造物では 形状，配筋，荷重状態などが異なっていることから，設 計においては12/1000を地震時における構造物変形の制限 值とした.

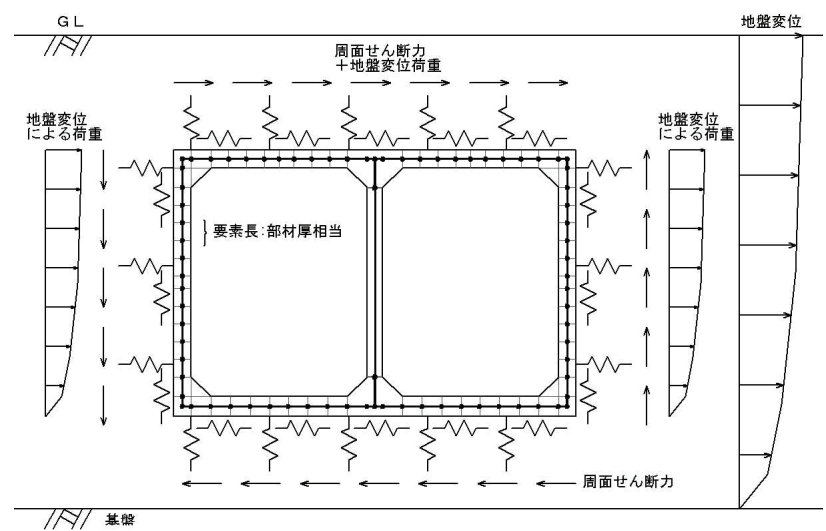

図-4 地下構造物の解析モデル例 


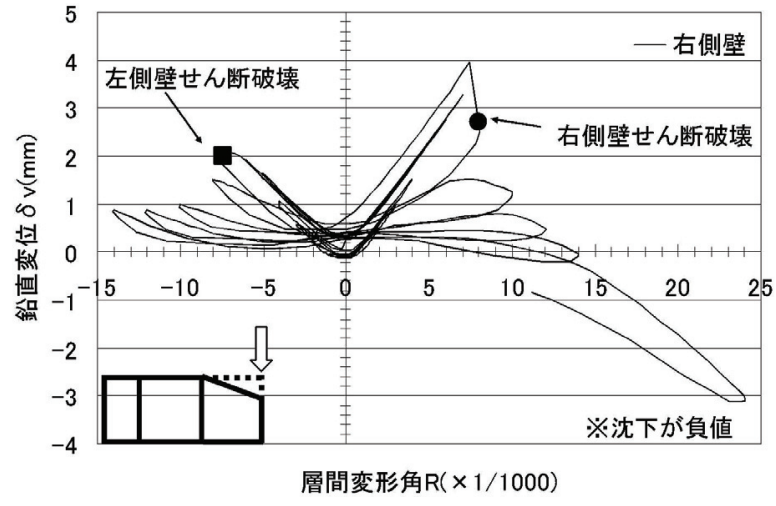

図-5 実験による鉛直変位一層間変形角関係 ${ }^{4}$

表-1 断面積の低減率

\begin{tabular}{c|c}
\hline 断面積の低減率 & $\begin{array}{c}\text { 右側壁の変位 } \\
(\mathrm{mm})\end{array}$ \\
\hline 低減率 0 (健全) & 0.0 \\
\hline 低減率 $1 / 2$ & 0.1 \\
\hline 低隇率 $1 / 10$ & 0.4 \\
\hline 低減率 $1 / 50$ & 1.9 \\
\hline 低隇率 $1 / 100$ & 3.6 \\
\hline 低減率 $1 / 200$ & 6.8 \\
\hline
\end{tabular}

\section{（3）断面積の低減率の設定}

せん断破壊による有効断面積の減少は，破壊の進行と ともに遷移するもので，設計実務においてこれを忠実に モデル化することは容易でないことから，先に設定した 層間変形角の制限值 12/1000 に達したときのせん断破壊 部位の鉛直変位から，せん断破壊後の断面積の低減率を 設定することとした．図-5 に示寸研究成果では，右側 壁の鉛直変位が約 $4 \mathrm{~mm}$ まで上昇した後，せん断破壊後 の層間変形角が増加するに従い徐々に下降し, 層間変形 角 $12 / 1000$ では $0.5 \mathrm{~mm}$ となる.

よって，断面積の低減率は，右側側壁の変位が $3.5 \mathrm{~mm}$ (4mm-0.5mm) になる值とすることとし，供試体を「而 震標準」に準拠して骨組み解析モデルとし，断面積をパ ラメータとした静的非線形解析を実施した. 表-1に示寸 ように低減率を $1 / 100$ とした場合，3.6mm と実験值とほぼ 同值となったことから，この值を設計上の断面積低減率 として設定することとした.

\section{(4) 断面二次モーメントの低減率の設定}

断面二次モーメントの低減率は, 図-6（注 : 図内の解 析値は実験時のものである）に示寸研究成果から推定し た. 実験では水平荷重が約 $2640 \mathrm{kN}$ に達して右側壁にせ 儿断破壊が発生した後に, 先に設定した層間変形角 $12 / 1000$ の時点では最大水平荷重の約 45\%（約 1200kN）

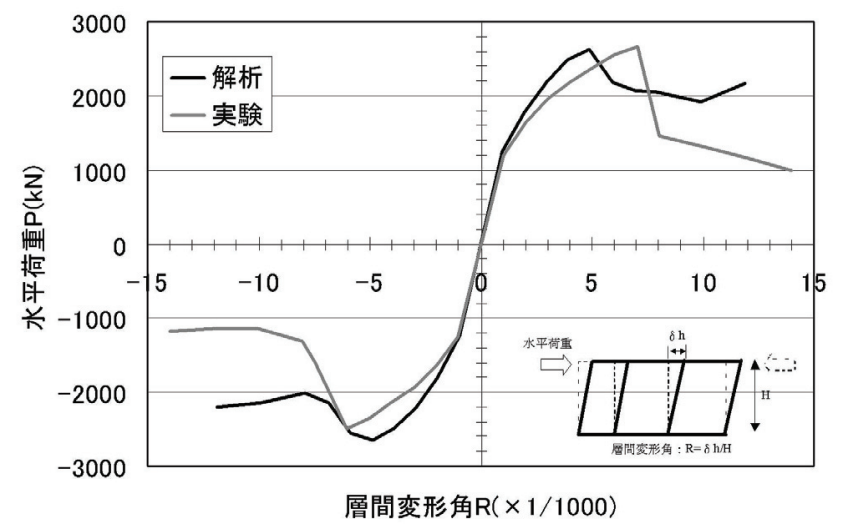

図-6 実験による水平荷重一層間変形角関係 ${ }^{4}$

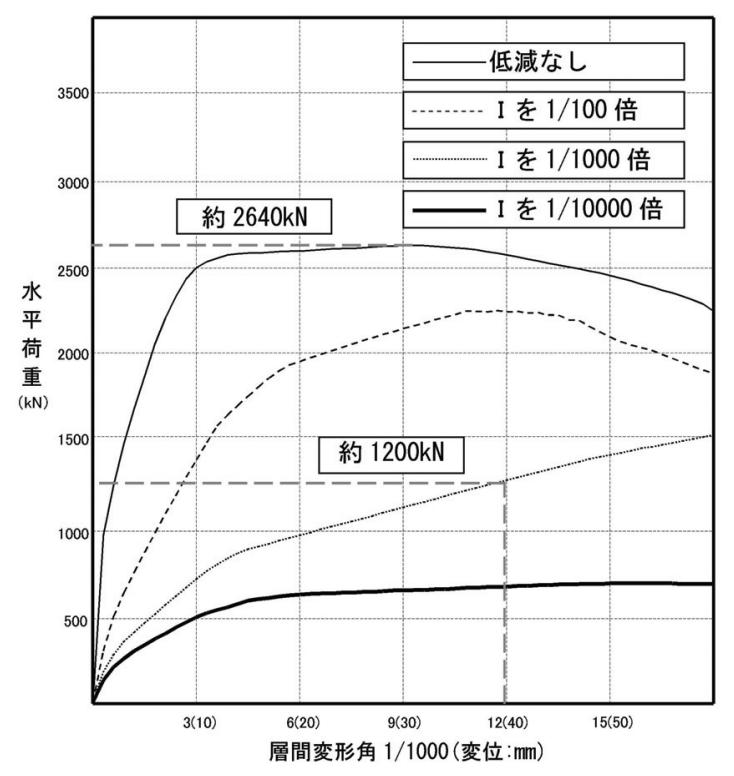

図-7 断面二次モーメントの低減率

に低下している.

この状況を，断面二次モーメントをパラメータとした 供試体の骨組みモデル（断面積の低減率の設定に用いた モデルと同じ）にて静的非線形解析により検討した.

図-7に示寸ように，せん断破壊部材の低減率を 1/1000 と設定した場合に，層間変形角 12/1000 の時点における 荷重の低下率（約 45\%）が最も実験結果を再現するもの であることから，これを断面二次モーメントの低減率と して設定することとした.

\section{4. 耐震設計手法の提案}

\section{(1) 耐震性能}

一般には，重要度の高い新設構造物であれば「而震標 準」に示される耐震性能项を要求性能とすることが妥当 である. しかし，新旧一体地下構造物のL2地震動に対 する要求性能を考える際には, 目標とする事業の速やか な執行と実現, 既設構造物に対する補強費用及び既設構 
造物の保有性能等を総合的に勘案し性能設定することが 必要である. 既設構造物の利用状況から部材補強が困難 な場合には，構造物全体系が崩壊しない性能として定義 される而震性能而を設計目標とすることが合理的である と判断した. このことは, 震災後の復旧事業が大規模に なるとしても，人命の損失を防ぐことを最優先と考えた ものである. また，せん断照査については，前述の既往 研究成果や, 構造物が地震時に液状化する可能性の低い 洪積層に拘束されているという特性を踏まえ，下記の条 件をすべて満たす側壁および部材の破壊が構造物の崩壊 に直接的に寄与しないと考えられる下床版に限り，せん 断照査を満足できなくても而震性能亚を担保できるもの と判断した.

1) 土に接している部材 (気中の壁では許容しない)

2) 連続する面部材（セグメント等の不連続部材では許 容しない)

3) 常時軸力が小さい部材

ここで，3)については実験時の常時軸力（軸圧縮耐力 に対寸る比率 0.02 ) や，せん断破壊先行型 RC 柱の変形 挙動についての実験 りにおける軸力（軸圧縮而扵に対す る比率 0.2 ) を参考に軸圧縮耐力の 1 割以下を目安とし た. また, L1 地震動に対する要求性能は, 「耐震標 準」に準じて耐震性能 I とした.

\section{（2）設計における制限値}

\section{a) せん断に対する制限値}

地震時のせん断照査は基本的に「而震標準」に準ずる こととするが，前述の条件下のもとに側壁および下床版 にせん断破壊を許容した場合は，建築限界および層間変 形角を照查指標とし，表-2を制限值とした.

\section{b) 曲げに対する制限値}

新旧構造物のすべての部材に対する照査は，せん断破 壊を生じる部材を除き「而震標準」に準じ，損傷レベル 3を制限值とした。

\section{(3) 設計手法}

\section{a) 設計の基本}

「而震標準」に準拠し，地盤ばねに支持された新設部 材および既設部材を一体にした骨組解析モデルによる 2 次元静的非線形解析を行なうことを基本とした. このと きの材料特性值は，既設構造物については実強度を用い， 新設部材については現行の設計基準に従うものとした.

表-2 せん断破壊を許容した場合の制限值

\begin{tabular}{c|c|c}
\hline 設計地震動 & 空間の制限值 & 層間変形角の制限値 \\
\hline $\mathrm{L} 2$ 2 地震動 & 建築限界学侵さない & $12 / 1000$ \\
\hline
\end{tabular}

\section{b) 設計手順}

検討した設計の手順を図-8に示す.

1) 初期解析

「而震標準」に準じた解析を行い，せん断破壊部材の 確認を行う.

2) 剛性低減解析

せん断破壊箇所（要素）が存在する場合は，せん断破 壊する要素の剛性（断面二次モーメント(I)および断面 積(A)）を低減して解析を行う。また，せん断破壊をモ デル化した再解析の結果において, 新たにせん断破壊箇 所が発生する場合には，せん断破壊個所の剛性低減を追 加した解析を実施し, 新たなせん断破壊箇所が発生しな くなるまでこれを繰返し行う。

剛性低減解析に用いる，I，A の低減率は，「3.(3),

(4)」において算出された以下の值を設定する.

・せん断破壊後の断面二次モーメントは健全な状態の 1/1000倍に低減する.

・ せん断破壊後の断面積は健全な状態の $1 / 100$ 倍に低減 する.

なお，上記低減率は，断面積及び断面二次モーメン 卜の低減率を設定した解析と同様に，1要素長を部材厚 相当とした場合に適用できる.

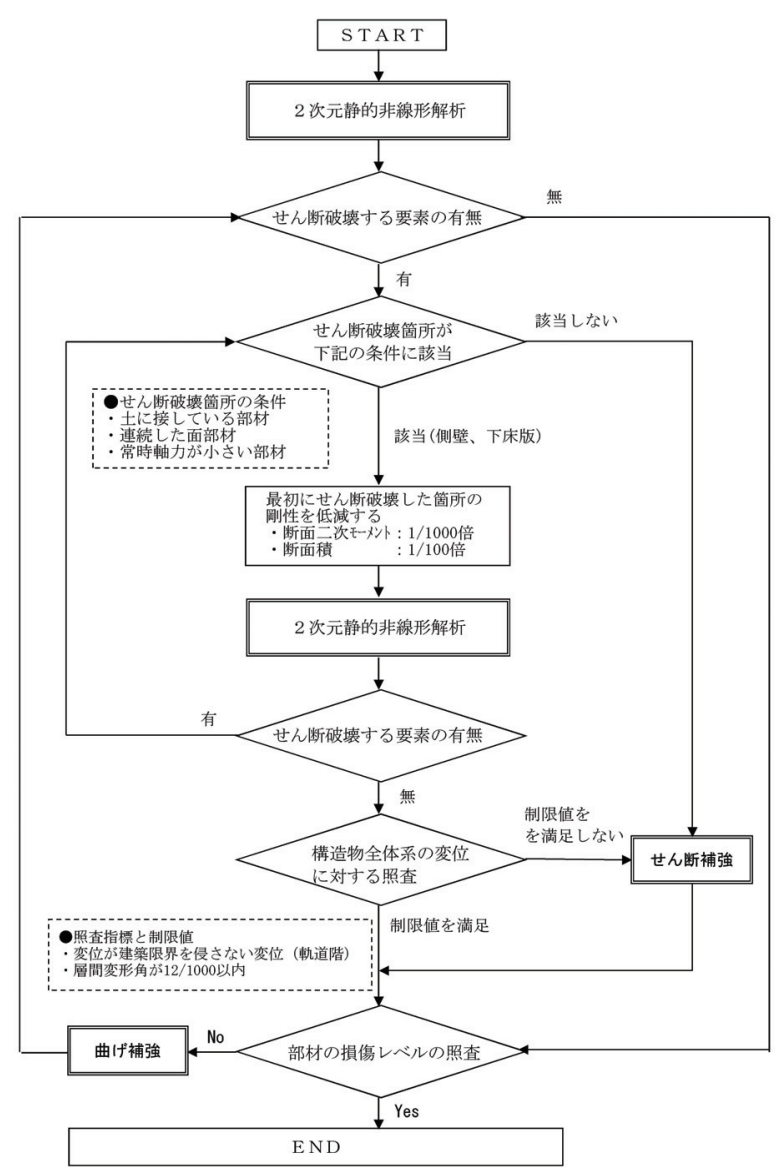

図-8 せん断破壊を許容した場合の設計手順 
3) 照査

剛性低減による繰返し解析の最終結果に対して, 「4.(2)」に示すせん断および曲げの照査を行う.

\section{5. 結論}

筆者らは，既存研究成果から，地震時に地下構造物の 側壁および下床版がせん断破壊を生じても，一定の条件 ならびに制限值を満足することで，人的被害を生じない 而震性能を確認・確保することが可能な而震設計手法を 検討・整理した。本設計手法は，土木学会技術推進機構 の技術評価制度により，成田空港内の駅舎増築に対する 手法として，その妥当性を評価された。同時に類似案件 への適用も示唆されており，本手法が，既存社会資本の 有効活用を視野に置いた諸検討の一助となることが期待 されるものである．本設計手法における解析は汎用ソフ トでの対応が可能であり, 高度な解析技術を要しない点 からも，類似案件の検討において参考となれば幸いであ る.
謝辞 : 本設計手法の検討に当たっては，ジェイアール総 研エンジニアリング (株) 西村昭彦社長に多大なるご尽 力を賜った. 未尾に深い謝意を表したい.

\section{参考文献}

1) 鉄道総合技術研究所：鉄道構造物等設計標準 - 同解 説 而震設計，1999.10.

2）本田国保，曽良岡宏，足立正信，市川卓也，相京泰 仁 : 実規模載荷実験に基づくボックスカルバートの 破壊過程, 第 2 回構造物の破壞過程解明に基づく地 震防災性向上に関するシンポジューム論文, pp.225230, 2001.3.

3) 曽良岡宏, 足立正信, 本田国保, 田中浩一: 地中ボ ックスカルバートの変形性能に関する実験的研究, コンクリート工学年次論文集, pp.1123-1128, Vol.23, No.3, 2001.

4) 曾良岡宏, 酒井俊朗, 足立正信 : 鉄筋コンクリート 製ボックスカルバートの実規模載荷実験, 電力土木, No.296, 2001.11.

5）高稲宜和，芳村学，中村孝也：鉄筋コンクリート柱 の崩壊変形に関寸る研究, 日本建築学会構造系論文 集，第 573 号，pp.153-160，2003.11.

(2012. 11. 15 受付)

\section{INVESTIGATION ON SEISMIC DESIGN METHOD CONSIDERING SHEAR FAILURE AT SIDE WALL OF UNDERGROUND STRUCTURES}

\section{Masahiro KANEKO, Atsushi TESHIGAWARA and Sumio TSUTSUMI}

Although it is possible to evaluate seismic performances of underground structure which consist of existing parts and newly constructed parts by adopting present designing criteria, the rational concept for the method to determine the seismic performances and to evaluate those structures has not been established for structures with existing parts designed and constructed decades ago.

The authors have studied seismic design method to analyze prescribed level of seismic performance in case of shear failure developed at side wall and lower slab by taking into account the conditions of underground structure.

This paper describes technological investigations on existing studies to consider the design method and the features of the method. 